\title{
Tubulin Beta Chain
}

National Cancer Institute

\section{Source}

National Cancer Institute. Tubulin Beta Chain. NCI Thesaurus. Code C104166.

Tubulin beta chain ( $444 \mathrm{aa}, \sim 50 \mathrm{kDa}$ ) is encoded by the human TUBB gene. This protein plays a role in both the structure and functioning of microtubules. 